\title{
AVALIAÇÃO DA ATIVIDADE DE Lactobacillus acidophilus NA BIOACESSIBILIDADE DE CÁLCIO EM LEITE FERMENTADO ADICIONADO DE RESÍDUO AGROINDUSTRIAL (BAGAÇO DE LARANJA)
}

\author{
Carolina A. Watanabe*, Juliana S. da Graça, Joyce G. S. Silva, Juliana A. L. Pallone, Anderson S. Sant'Ana
}

\section{Resumo}

Dentre a grande variedade de fatores que influem na saúde da população encontram-se as deficiências nutricionais, entre elas a deficiência em cálcio, a qual esta interligada com o desenvolvimento da osteoporose e atinge grande parte da população brasileira. Sabe-se também, que o Brasil é um dos maiores produtores de laranja do mundo e que os subprodutos desta indústria podem girar em torno de 40 a $60 \%$ do volume produzido. Além disso, frutas cítricas possuem quantidades consideráveis de minerais importantes para a nutrição humana como cálcio, magnésio e potássio.

\section{Palavras-chave:}

Reaproveitamento de resíduos, bactérias ácido lácticas, micronutrientes.

\section{Introdução}

Dentre os diversos benefícios associados ao consumo de probióticos em produtos fermentados, encontram-se relatos sobre 0 aumento da biodisponibilidade de minerais. Portanto, a proposta deste estudo visa, observar o impacto da adição de farinha de bagaço de laranja na quantidade total e bioacessível de cálcio em leites fermentados.

\section{Resultados e Discussão}

A produção dos leites fermentados foi realizada através da adição da cultura probiótica (Lactobacillus acidophilus) em leite UHT (Ninho, Nestlé) e incubação em banho maria a $42^{\circ} \mathrm{C}$ até atingir $\mathrm{pH} 4,6-4,7$. Os leites fermentados contendo farinha de bagaço de laranja (FBL), foram acrescidos de $5 \%$ da mesma anterior a sua fermentação. As metodologias utilizadas para avaliar a contagem de bactérias probióticas e a bioacessibilidade de cálcio foram o plaqueamento (pour plate) em MRS ágar e o método in vitro de diálise (JOVANì et al., 2001), respectivamente. Para as análises estatísticas foram realizadas ANOVA e a comparação de médias por Tukey $(\mathrm{p}<0,05)$.

As curvas de crescimento e de vida de prateleira são apresentadas na figura 1. Observa-se que o tempo de crescimento da formulação com FBL foi menor (com variação de $6 \mathrm{~h}$ ) quando comparada a controle. Já na análise de vida de prateleira, as contagens das duas amostras não variaram significativamente durante 0 período avaliado.
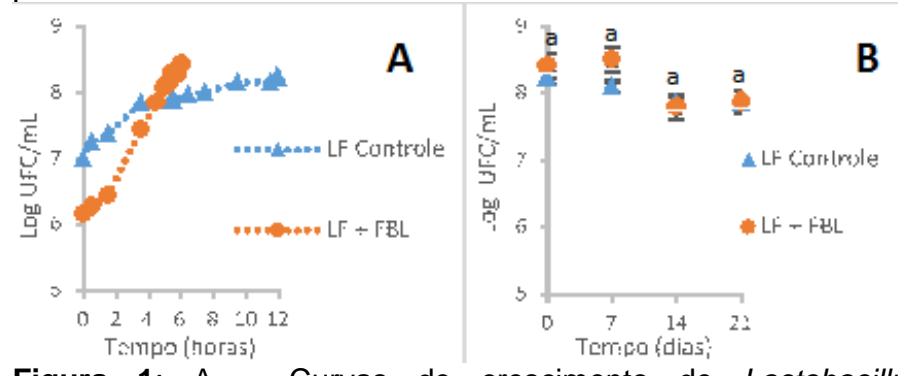

Figura 1: A - Curvas de crescimento de Lactobacillus acidophilus nas duas formulações de leite fermentado. LF (leite fermentado); FL (farinha de bagaço de laranja). B - Contagens (UFC/mL) de Lactobacillus acidophilus durante o período de vida de prateleira dos leites fermentados produzidos.
Os resultados da concentração de cálcio total e dialisado nas amostras de leite fermentado são apresentados na tabela 1 . Observa-se que a adição de FBL aumentou a quantidade total e dialisada de cálcio na amostra de leite fermentado.

Tabela 1: Concentração de cálcio total e dialisado $(\mu \mathrm{g} / \mathrm{g})$ dos leites fermentados produzidos.

\begin{tabular}{|c|c|c|c|}
\hline Amostra & Total $(\boldsymbol{\mu g} / \mathbf{g})$ & $\begin{array}{c}\text { Dialisado } \\
(\boldsymbol{\mu} \mathbf{g} / \mathbf{g})\end{array}$ & $\begin{array}{c}\text { Dialisado } \\
(\mathbf{\%})\end{array}$ \\
\hline Leite UHT* & 1153,10 & - & - \\
\hline Leite + FL & 1423,45 & - & - \\
\hline LF Controle & $1261,67 \pm 48,42^{\text {a }}$ & $51,33 \pm 3,55^{\text {a }}$ & 4,07 \\
\hline LF + FL & $1796,30 \pm 23,09^{\mathrm{b}}$ & $95,07 \pm 10,44^{\mathrm{b}}$ & 5,29 \\
\hline
\end{tabular}

Legenda: Letras diferentes na mesma coluna indicam médias significativamente diferentes $(p<0,05)$. ${ }^{*}$ Resultado informado no rótulo do produto. ${ }^{* *}$ Resultado obtido pela soma da concentração de cálcio presente na farinha de bagaço de laranja (dados não demonstrados) e no leite.

\section{Conclusões}

Conclui-se que a adição de FBL impactou na redução do tempo de fermentação dos leites fermentados, mantendo contagens similares durante a vida de prateleira quando comparada ao controle. Ainda, a adição de FBL auxiliou significativamente no aumento das concentrações de cálcio total e dialisada das amostras.

\section{Agradecimentos}

C. A. Watanabe gostaria de agradecer ao PIBIC/CNPq, a FAPESP, e aos Laboratórios de Microbiologia Quantitativa de Alimentos e Análise de Alimentos II da Faculdade de Engenharia de Alimentos da UNICAMP pela oportunidade da realização desse projeto.

BERGILLOS-MECA, T. et al. The probiotic bacterial strain lactobacillus fermentum D3 increases in vitro the bioavailability of $\mathrm{Ca}, \mathrm{P}$, and $\mathrm{Zn}$ in fermented goat milk. Biological Trace Element Research, v. 151, n. 2, p. 307-314, 2013

JOVANÍ, M. et al. Calcium, iron, and zinc uptake from digests of infant formulas by caco-2 cells. Journal of Agricultural and Food Chemistry, 49, 3480-3485, 2001.

REKHA, C. R.; VIJAYALAKSHMI, G. Bioconversion of isoflavone glycosides to aglycones, mineral bioavailability and vitamin B complex in fermented soymilk by probiotic bacteria and yeast. Journal of Applied Microbiology, v. 109, n. 4, p. 1198-1208, 2010. 